\title{
EVALUASI BEBAS TUJUAN: IMPLEMENTASI DALAM PELATIHAN KEPEWARAAN MAHASISWA
}

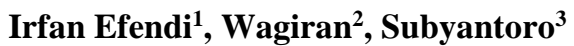 \\ ${ }^{1}$ STKIP Nahdlatul Ulama Indramayu \\ ${ }^{1}$ Mahasiswa S3 Ilmu Pendidikan Bahasa, Pascasarjana Universitas Negeri Semarang \\ 1email: irfanlibels66@gmail.com \\ 2,3IImu Pendidikan Bahasa, Pascasarjana Universitas Negeri Semarang \\ 2email: wagiran@mail.unnes.ac.id \\ 3email: bintoro@mail.unnes.ac.id
}

\begin{abstract}
In the principle, the goal-free evaluation model has the advantage of being able to consider possible influences, not only those that are planned, but things that are considered as other byproducts that arise from the product, so that novelty can be found in this model. The purpose of this study was to evaluate the application of the student host training model at STKIP NU Indramayu. The method used in this study is an experiment using a test technique. The tests used are linguistic knowledge and host tests. The results of the student's linguistic knowledge test when they were about to take part in the host training only reached 65.30. Based on the benchmark reference assessment with a scale of ten calculations at 56\%-65\% mastery intervals, it is categorized as moderate. The host practice test for STKIP NU Indramayu students before the host training was carried out only reached 62.90 in the moderate category. The host practice test of STKIP NU Indramayu students after attending the training reached 77.80. Based on the benchmark reference assessment with an interval of 76\%-85\% mastery level percentage is categorized as good. Thus, it can be concluded that the evaluation of student host training programs needs to be continuously developed by universities in Indonesia.
\end{abstract}

Keywords: goal-free evaluation, implementation of host training for students

Abstrak: Pada prinsipnya, model evaluasi bebas tujuan (goal free evaluation model) memiliki kelebihan dapat mempertimbangkan kemungkinan pengaruh, bukan hanya yang direncanakan, tetapi hal yang diperhatikan sebagai sampingan lain yang muncul dari produk, sehingga kebaruan dapat ditemukan dalam model ini. Tujuan penelitian ini yaitu untuk mengevaluasi penerapan model pelatihan kepewaraan mahasiswa di STKIP NU Indramayu. Metode yang digunakan dalam penelitian ini adalah eksperimen dengan menggunakan teknik tes. Tes yang digunakan adalah pengetahuan kebahasaan dan tes kepewaraan. Hasil tes pengetahuan kebahasaan mahasiswa saat akan mengikuti pelatihan kepewaraan hanya mencapai 65,30. Berdasarkan penilaian acuan patokan dengan penghitungan skala sepuluh pada interval penguasaan 56\%-65\% terkategori sedang. Tes praktik kepewaraan mahasiswa STKIP NU Indramayu sebelum dilakukan pelatihan kepewaraan hanya mencapai 62,90 terkategori sedang. Tes praktik kepewaraan mahasiswa STKIP NU Indramayu setelah mengikuti pelatihan mencapai 77,80 . Berdasarkan penilaian acuan patokan dengan interval persentase tingkat penguasaan 76\%-85\% terkategori baik. Dengan demikian, dapat disimpulkan bahwa evaluasi program pelatihan kepewaraan mahasiswa perlu terus dikembangkan oleh perguruan tinggi di Indonesia.

Kata Kunci: evaluasi bebas tujuan, implementasi pelatihan kepewaraan pada mahasiswa

\section{PENDAHULUAN}

Keterampilan

sesungguhnya merupakan berbicara

salah satu keterampilan berbahasa yang paling besar peranannya untuk mencapai kesuksesan bagi mahasiswa di perguruan tinggi. 
Kemampuan untuk berkomunikasi secara kompeten sangat penting untuk kepuasan pribadi, pencapaian akademis, dan kesuksesan karier profesional (Morreale \& Pearson, 2008).

Salah satu keterampilan berbicara yang dimaksud adalah kepewaraan. Kepewaraan merupakan salah satu bagian terpenting dalam agenda di perguruan tinggi. Rokhman dan Pristiwati (2015) mengemukakan kepewaraan pada saat ini merupakan sebuah fenomena global tanpa batas. Itulah sebabnya, dalam dunia kepewaraan sebagai sesuatu pengalaman yang mempesona dan menarik.

Begitu mempesonanya dunia kepewaraan mahasiswa di perguruan tinggi, ternyata tidak diimbangi dengan pelatihan yang memadai. Hal itu dibuktikan dengan hasil observasi praktik kepewaraan pada acara formal oleh penulis di lima perguruan tinggi, baik dalam acara wisuda, dies natalis maupun acara formal lainnya, kegiatan kepewaraan cenderung dilakukan oleh dosen atau karyawan, bukan oleh mahasiswa, seperti STKIP Nahdlatul Ulama Indramayu, Universitas Swadaya Gunung Jati, Universitas Muhammadiyah Cirebon, IAIN Syech Nurjati Cirebon, dan Universitas Sultan Agung Semarang. Melihat pemetaan observasi kepewaraan di beberapa perguruan tinggi itu menunjukkan bahwa pelatihan kepewaraan bagi mahasiswa perlu dilakukan dan perlu dievaluasi.

Evaluasi menurut KBBI (2001) adalah suatu penilaian dimana penilaian tersebut ditujukan terhadap orang yang lebih tinggi ataupun yang lebih tahu kepada orang yang lebih rendah, baik dari sisi jabatan strukturnya atau orang yang lebih rendah keahliannya. Gagasan Asrul (2014) evaluasi dapat dimaknai sebagai proses sistematis, berkelanjutan, serta menyeluruh dalam rangka untuk mengendalikan, menjamin, serta menetapkan kualitas berbagai komponen pembelajaran. Stufflebeam
(1971) menyatakan bahwa proses evaluation to serve implementing decision.

Definisi-definisi evaluasi dari para ahli, oleh Mutrofin (2010:8) dirangkum bahwa untuk mendeskripsikan evaluasi sebagai kerangka umum di dalamnya terdapat makna-makna sebagai berikut. 1) evaluasi sebagai judgement profesional, 2) evaluasi sebagai pengukuran, 3) evaluasi sebagai analisis kesesuaian antara kinerja dengan tujuan, sasaran atau standar kerja, 4) evaluasi berorientasi pada keputusan, 5) evaluasi responsif atau bebas tujuan.

Model-model evaluasi dapat dikelompokkan dalam berbagai cakupan. Said Hamid Hasan (2009) mengelompokkan evaluasi 1) model evaluasi kuantitatif, yang meliputi model Tyler, model teoretik Tylor dan Maguire, model pendekatan sistem Alkin, model Countenance Stake, model CIPP, model ekonomi mikro; 2) model evaluasi kualitatif, yang meliputi model studi kasus, model iluminatif, dan model respon.

Menurut Kaufman dan Thomson (1980) menjelaskan delapan model evaluasi, yaitu 1) Goal Oriented Model yang dikembangkan Ralph W. Tyler; 2) Goal Free Evaluation Model yang dikembangkan oleh michael Scriven; 3) Formative-Sumative Evaluation Model yang dikembangkan Michael Scriven; 4) Countenance Evaluation Model yang dikembangkan R.E. Stake, 5) Responsive Evaluation Model yang dikembangkan R.E. Stake; 6) CSEUCLA Evaluation Model ; 7) CIPP Model yang dikembangkan Daniel L. Stufflebeam; dan 8) Discrepancy Model yang dikembangkan malcolm M.Provus.

Evaluasi pada dasarnya merupakan kegiatan untuk meningkatkan kualitas, kinerja, atau produktivitas suatu lembaga atau objek evaluasi. Dengan evaluasi pula, kita bisa mengukur sejauh mana suatu program itu tercapai. Evaluasi juga dapat mengukur atau mengetahui perkembangan 
pelatihan, bakat, minat, sikap, kecakapan, pengetahuan, mnotivasi, dan keterampilan. Model evaluasi yang kita pilih tentu disesuaiakan dengan maksud dan tujuan evaluasi. Salah satu model evaluasi yang penulis tawarkan adalah model evaluasi bebas tujuan.

Model evaluasi bebas tujuan adalah model evaluasi yang dikembangkan oleh Michael Scriven (1974) dengan tujuan memalingkan dari tujuan evaluasi. Menurut Scriven, dalam melaksanakan evaluasi program , evaluator tidak perlu memperhatikan apa yang menjadi tujuan program. Hal yang diutamakan dalam program tersebut adalah bagaimana kerja suatu program, yaitu dengan mengidentifikasi penampilan-penampilan yang terjadi, baik bersifat positif (yang diharapkan) dan hal negatif (yang tidak diharapkan).

Ciri-ciri evaluasi bebas tujuan adalah evaluator sengaja menghindar untuk mengetahui tujuan program; tujuan yang telah dirumuskan terlebih dahulu tidak dibenarkan menyempitkan evaluasi; evaluasi bebas tujuan berfokus pada hasil yang sebenarnya, bukan pada hasil yang direncanakan; hubungan evaluator dan manajer atau dengan karyawan dibuat seminimal mungkin; evaluasi menambah kemungkinan dampak yang tidak diramalkan.

Model evaluasi yang akan digunakan dalam penelitian ini bertujuan untuk mengimplementasikan program pelatihan kepewaraan mahasiswa. Penelitian ini difokuskan pada cetak biru program; mengembangkan desain dan evaluasi; mengidentifikasikan tujuan evaluasi; memastikan pelaksanaan program telah mencapai tujuan; menjaring dan menganalisis data; menyusun laporan evaluasi hasil evaluasi; pemanfaatan hasil evaluasi. Berikut ini penulis paparkan bagan Goal Free Evaluation.

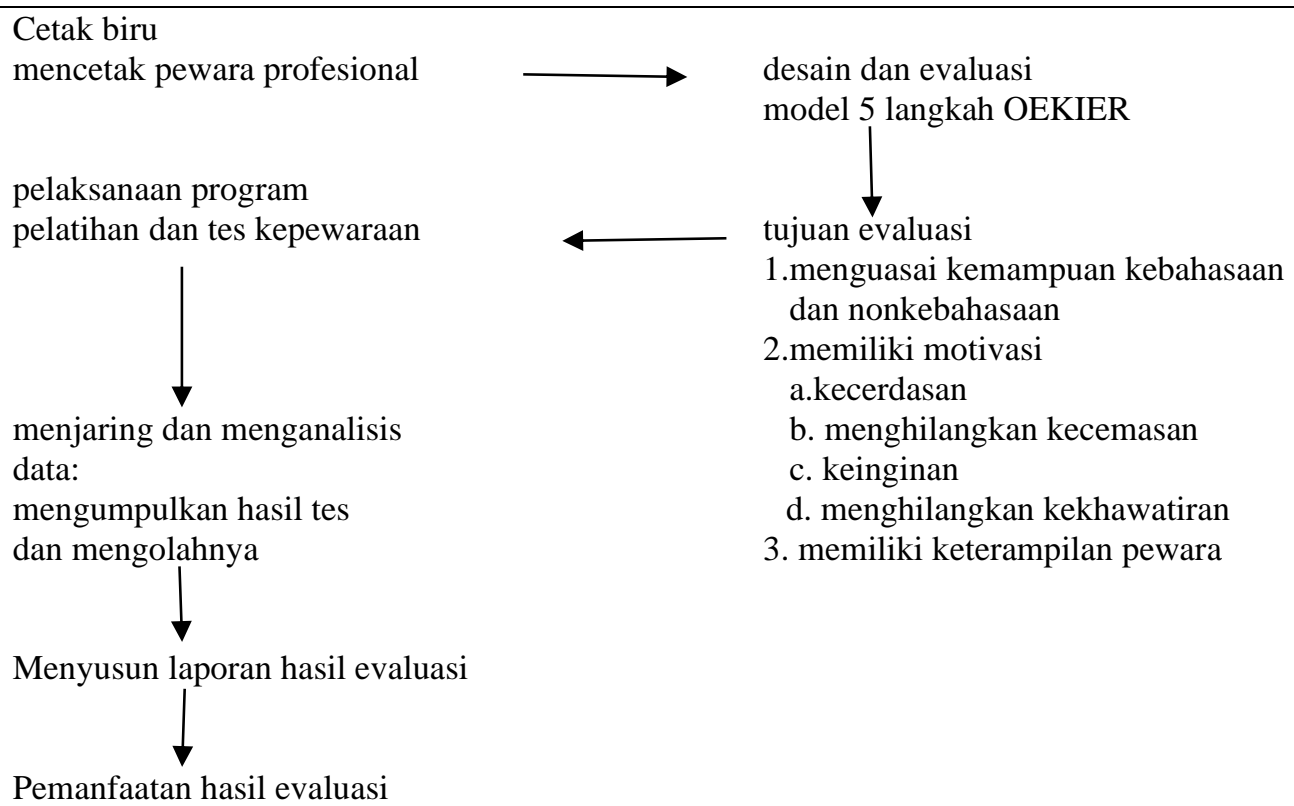

Menyusun laporan hasil evaluasi

Pemanfaatan hasil evaluasi

Gambar 1. bagan Goal Free Evaluation

Bagan di atas bila diuraiakan akan tampak sebagai berikut. Pertama bahwa pelatihan kepewaraan ini dirancang untuk mencetak pewara profesional. Kedua, penulis mendesain model pelatihan kepewaraan OEKIER, yang penulis 
padukan dari Joyce dan Weil (2011) orientasi, latihan partisipasi, pelaksanaan simulasi, dan wawasan partisipan serta Zulaeha (2016) orientasi, perumusan hipotesis, penjelasan istilah, eksplorasi, pembuktian, dan generalisasi. Lima fase yang dimaksud, yaitu Fase 1, Orientasi.

Fase ini meliputi 1). mahasiswa mengamati penampilan seorang pewara ahli melalui tayangan video; 2) mahasiswa mendeskripsikan hasil pengamatan pada tayangan video. Fase 2,Eksplorasi. Pada fase ini mahasiwa menampilkan teknik kepewaraan berdasarkan hasil pengamatan pada tayangan pewara ahli. Hal-hal yang harus diperhatikan adalah 1) gerakan anggota badan (gestur), mimik (ekspresi), dan pandangan (visual) atau wiraga; 2) kemampuan bertutur (runtut, logis, mudah dipahami, kenikmatan menjadi pewara) atau disebut wirasa; 3) jeda, intonasi, ketepatan pengucapan kata, tinggi rendanya ucapan/irama atau disebut wirama. Fase 3 Konseptualisasi. Pada fase ini mahasiswa berdiskusi dan bertanya jawab tentangtentang hal-hal yang berkaitan dengan kepewaraan, baik unsur kebahasaan, nonkebahasaan, maupun unsur-unsur penunjang lainnya sehingga mahasiswa memahami secara konsep tentang kepewaraan. Fase 4 Implementasi. Pada fase ini, mahasiswa berlatih kepewaraan secara berulang sesuai dengan hasil pengamatan dan pemahaman mahasiswa secara konseptual tentang kepewaraaan. Mahasiswa mencoba mengimplementasikan dan mengaktualisasikan dirinya berlaku seperti seorang pewara sesuai pemahaman mereka tentang kepewaraan. Fase 5 Evaluasi dan Refleksi. Fase ini berisi evaluasi dilakukan penilaian terhadap kemampuan membawakan kepewaraan dan direfleksi oleh peneliti dan ahli kepewaraan dan ahli bahasa. Implementasi dan penampilan sebagai seorang pewara yang dilakukan mahasiswa pada fase 4 dievaluasi dan menjadi bahan refleksi untuk perbaikan latihan berikutnya.

Ketiga, tujuan evaluasi ini meliputi penguasaan kemampuan kebahasaan dan nonkebahasaan, motivasi, dan keterampilan. Keempat, melaksanakan program pelatihan dan tes kepewaraan. Kelima, mengolah hasil tes kepewaraan untuk evaluasi program. Keenam, menyusun laporan hasil evaluasi. Ketujuh, memanfaatkan hasil evaluasi kepada stake holder atau publik.

Kelebihan evaluasi bebas tujuan dalam pelatihan kepewaraan mahasiswa adalah 1). evaluator tidak perlu memperhatikan secara rinci setiap komponen, tetapi hanya menekankan pada bagaimana mengurangi prasangka (bias); 2) model ini menganggap pengguna sebagai audiens utama; 3) pengaruh konsep pada masyarakat, bahwa tanpa mengetahui tujuan dari kegiatan yang telah dilakukan, seorang penilai bisa melakukan evaluasi; 4) mendorong pertimbangan setiap kemungkinan pengaruh tidak saja yang direncanakan, tetapi juga dapat diperhatikan sampingan lain yang muncul dari produk.

Kelemahan model evaluasi bebas tujuan ini, yaitu 1) pada umumnya bebas menjawab pertanyaan penting, seperti apa pengaruh yang telah diperhitungkan dalam suatu peristiwa dan bagaimana mengidentifikasi pengaruh tersebut; 2) model ini tidak terlalu berhasil dalam menggambarkan bagaimana evaluasi sebaiknya benar-benar dilaksanakan;3) tidak merekomendasikan bagaimana menghasilkan penilaian kebutuhan , walaupun pada akhirnya mengarah pada penilaian kebutuhan; 4) diperlukan evaluator yang benar-benar kompeten untuk dapat melaksanakan evaluasi model ini; 5) langkah sistematis yang harus 
dilakukan dalam evaluasi hanya menekankan pada objek sasaran saja.

\section{METODE PENELITIAN}

Penelitian ini menggunakan deskriptif eksperimental dengan menerapkan model evaluasi bebas tujuan (goal free evaluation model) dengan tujuan melihat hasil yang akhir yang perlu diperbaiki. Objek dalam penelitian ini adalah mahasiswa Program Studi Pendidikan Bahasa dan Sastra Indonesia STKIP NU Indramayu. Teknik penelitian ini menggunakan tes pengetahuan dan tes kepewaraan.

\section{HASIL DAN PEMBAHASAN}

Dalam penelitian ini, penilaian hanya difokuskan pada tes pengetahuan kebahasaan dan tes praktik kepewaraan. Hasil tes tulis pengetahuan berbahasa kepada sepuluh mahasiswa STKIP NU Indramayu peserta kepewaraan tampak pada tabeli berikut.

\begin{tabular}{|c|c|c|c|c|}
\hline \multirow{2}{*}{ No Urut Mhs } & Fonologi & Morfologi & Sintaksis & Total \\
\hline & $(0-30)$ & $(0-30)$ & $(0-40)$ & Skor \\
\hline 1. & 20 & 21 & 24 & 65 \\
\hline 2. & 21 & 22 & 24 & 67 \\
\hline 3. & 19 & 20 & 23 & 62 \\
\hline 4. & 20 & 22 & 19 & 61 \\
\hline 5. & 21 & 21 & 22 & 63 \\
\hline 6. & 19 & 19 & 21 & 59 \\
\hline 7. & 21 & 24 & 24 & 71 \\
\hline 8. & 22 & 20 & 19 & 61 \\
\hline 9. & 19 & 20 & 21 & 60 \\
\hline 10. & 20 & 22 & 24 & 65 \\
\hline$\sum$ & 204 & 211 & 221 & 653 \\
\hline $\mathrm{R}$ & 20,40 & 21,10 & 22,10 & 65,30 \\
\hline
\end{tabular}

Data di atas menunjukkan bahwa tes pengetahuan kebahasaan yang diperoleh mahasiswa STKIP NU Indramayu hanya mencapai rata-rata 65,30. Berdasarkan acuan penentuan patokan dengan penghitungan persentase untuk skala sepuluh pada interval persentase tingkat penguasaan $56 \%-65 \%$ terkategori sedang (Nurgiantoro, 2001:400). Dengan demikian bahwa pelatihan kepewaraan dari segi pengetahuan kebahasaan dan nonkebahasaan perlu dilatihkan pada mahasiswa.

Selanjutnya adalah tes praktik kepewaraan. Hasil tes praktik pewara mahasiswa STKIP NU Indramayu sebelum pelatihan kepewaran (pretes) tampak pada tabel berikut.

Tabel 2. Hasil pretes kepewaraan mahasiswa STKIP NU Indramayu

\begin{tabular}{ccccccc}
\hline & \multicolumn{7}{c}{ Skor } \\
\cline { 2 - 6 } $\begin{array}{c}\text { No.urut } \\
\text { Mahasiswa }\end{array}$ & Lafal & Intonasi & $\begin{array}{c}\text { Tata } \\
\text { bahasa }\end{array}$ & $\begin{array}{c}\text { Kelancara } \\
\text { dan } \\
\text { kewajaran }\end{array}$ & Penampilan & $\begin{array}{c}\text { Total } \\
\text { skor }\end{array}$ \\
\cline { 2 - 6 } & $0-20$ & $0-20$ & $0-20$ & $0-20$ & $0-20$ & 62 \\
2. & 13 & 11 & 13 & 10 & 15 & 64 \\
3. & 14 & 10 & 14 & 11 & 16 & 64
\end{tabular}




\begin{tabular}{|c|c|c|c|c|c|c|}
\hline \multirow{3}{*}{$\begin{array}{c}\text { No.urut } \\
\text { Mahasiswa }\end{array}$} & \multicolumn{6}{|c|}{ Skor } \\
\hline & Lafal & Intonasi & $\begin{array}{c}\text { Tata } \\
\text { bahasa }\end{array}$ & $\begin{array}{l}\text { Kelancara } \\
\text { dan } \\
\text { kewajaran }\end{array}$ & Penampilan & \multirow[t]{2}{*}{$\begin{array}{l}\text { Total } \\
\text { skor }\end{array}$} \\
\hline & $0-20$ & $0-20$ & $0-20$ & $0-20$ & $0-20$ & \\
\hline 4. & 10 & 13 & 12 & 12 & 14 & 61 \\
\hline 5. & 11 & 12 & 15 & 10 & 15 & 63 \\
\hline 6. & 9 & 13 & 11 & 11 & 13 & 58 \\
\hline 7. & 13 & 14 & 14 & 13 & 14 & 71 \\
\hline 8. & 12 & 11 & 13 & 12 & 12 & 60 \\
\hline 9. & 10 & 13 & 12 & 11 & 14 & 60 \\
\hline 10. & 13 & 14 & 13 & 13 & 14 & 66 \\
\hline$\sum$ & 117 & 123 & 130 & 118 & 139 & 624 \\
\hline $\mathrm{R}$ & 11,7 & 12,3 & 13,0 & 11,8 & 13,9 & 62,4 \\
\hline
\end{tabular}

Tabel di atas menunjukkan bahwa rata-rata praktik kepewaraan mahasiswa STKIP NU Indramayu hanya mencapai 62,90. Berdasarkan acuan penentuan patokan dengan penghitungan persentase untuk skala sepuluh pada interval persentase tingkat penguasaan56\%-65\% terkategori sedang (Nurgiantoro, 2001). Dengan demikian bahwa pelatihan kepewaraan perlu dilaksanakan pada mahasiswa, agar lebih terampil dan profesional.

Hasil tes praktik pewara mahasiswa STKIP NU Indramayu setelah pelatihan kepewaran (postes) tampak pada tabel berikut.

Tabel 3 Hasil postes kepewaraan mahasiswa STKIP NU Indramayu

\begin{tabular}{|c|c|c|c|c|c|c|}
\hline \multirow{3}{*}{$\begin{array}{c}\text { No. urut } \\
\text { Mahasiswa }\end{array}$} & \multicolumn{6}{|c|}{ Skor } \\
\hline & Lafal & intonasi & $\begin{array}{c}\text { Tata } \\
\text { bahasa }\end{array}$ & $\begin{array}{c}\text { Kelancaran dan } \\
\text { kewajaran }\end{array}$ & penampilan & \multirow{2}{*}{$\begin{array}{l}\text { Total } \\
\text { skor }\end{array}$} \\
\hline & $0-20$ & $0-20$ & $0-20$ & $0-20$ & $0-20$ & \\
\hline 1. & 18 & 15 & 15 & 13 & 17 & 78 \\
\hline 2. & 17 & 13 & 16 & 17 & 18 & 81 \\
\hline 3. & 16 & 14 & 17 & 16 & 17 & 80 \\
\hline 4. & 13 & 16 & 14 & 17 & 16 & 76 \\
\hline 5. & 15 & 16 & 15 & 15 & 17 & 78 \\
\hline 6. & 13 & 15 & 15 & 14 & 14 & 71 \\
\hline 7. & 15 & 17 & 16 & 17 & 18 & 83 \\
\hline 8. & 14 & 16 & 14 & 16 & 16 & 76 \\
\hline 9. & 13 & 16 & 15 & 15 & 16 & 75 \\
\hline 10. & 16 & 15 & 15 & 16 & 18 & 80 \\
\hline$\sum$ & 150 & 153 & 152 & 156 & 167 & 778 \\
\hline $\mathrm{R}$ & 15,0 & 15,3 & 15,2 & 15,6 & 16,7 & 77,8 \\
\hline
\end{tabular}

Tabel di atas menunjukkan bahwa rata-rata praktik kepewaraan mahasiswa STKIP NU Indramayu setelah mengikuti pelatihan mencapai 77,80. Berdasarkan acuan penentuan patokan dengan penghitungan persentase untuk skala sepuluh pada interval persentase tingkat penguasaan $76 \%-85 \%$ terkategori baik (Nurgiantoro, 2001:400). Dengan demikian bahwa pelatihan kepewaraan perlu dilaksanakan berkelanjutan (sustainable) pada mahasiswa, agar lebih terampil dan profesional.

Data hasil tes kepewaraan mahasiswa STKIP NU Indramayu sebelum dan sesudah dapat dilihat berdasarkan pengolahan data SPSS seperti berikut. 
Tabel 4. Tests of Normality

\begin{tabular}{|l|l|r|r|r|r|r|r|}
\hline & \multirow{2}{*}{ Kelas } & \multicolumn{3}{|c|}{ Kolmogorov-Smirnova } & \multicolumn{3}{|c|}{ Shapiro-Wilk } \\
\cline { 3 - 8 } & & Statistic & \multicolumn{1}{c|}{ Df } & Sig. & Statistic & df & Sig. \\
\hline \multirow{2}{*}{ Hasilbelajar } & Pretes & .158 & 10 & $.200^{*}$ & .878 & 10 & .125 \\
& postes & .138 & 10 & $.200^{*}$ & .968 & 10 & .874 \\
\hline
\end{tabular}

*. This is a lower bound of the true significance.

a. Lilliefors Significance Correction

Berdasarkan data tes of normality diperoleh hasil nilai signifikan pretes $=0,125$ dan postes 0,874 lebih dari 0,05. Dengan demikian, kedua data tersebut berdistribusi normal

Tabel 5. Test of Homogeneity of Variances

Hasilbelajar

\begin{tabular}{|c|c|c|c|}
\hline Levene Statistic & $\mathrm{df1}$ & $\mathrm{df2}$ & Sig. \\
\hline .002 & 1] & 18 & .968 \\
\hline
\end{tabular}

Berdasarkan data tes of homogeneity diperoleh hasil nilai signifikansi $0,968>$ 0,05 . Dengan demikian data tersebut heterogen dan tidak memiliki varian yang sama dari nilai tersebut.

Tabel 6. Paired Samples Test

\begin{tabular}{|c|c|c|c|c|c|c|c|c|c|}
\hline & & \multicolumn{5}{|c|}{ Paired Differences } & \multirow[t]{3}{*}{$t$} & \multirow[t]{3}{*}{ df } & \multirow[t]{3}{*}{ Sig. (2-tailed) } \\
\hline & & \multirow[t]{2}{*}{ Mean } & \multirow[t]{2}{*}{ Std. Deviation } & \multirow[t]{2}{*}{ Std. Error Mean } & \multicolumn{2}{|c|}{$\begin{array}{l}\text { 95\% Confidence Interval of the } \\
\text { Difference }\end{array}$} & & & \\
\hline & & & & & Lower & Upper & & & \\
\hline Pair 1 & pretes-postes & -15.400 & 2.119 & .670 & -16.916 & -13.884 & -22.985 & 9 & .000 \\
\hline
\end{tabular}

Data di atas menunjukkan bahwa taraf signifikansi sebesar $0,000<\alpha=0,05$ bermakna terdapat perbedaan hasil tes kepewaraan yang signifikan antara sebelum perlakuan pelatihan dan sesudah diberikan pelatihan.

Tabel 7. Paired Samples Statistics

\begin{tabular}{|rr|r|r|r|r|}
\hline & \multicolumn{1}{|c|}{ Mean } & $\mathrm{N}$ & Std. Deviation & Std. Error Mean \\
\hline \multirow{2}{*}{ Pair 1 } & pretes & 62.40 & 10 & 3.688 & 1.166 \\
& postes & 77.80 & 10 & 3.458 & 1.093 \\
\hline
\end{tabular}

Data tes kepewaraan tersebut diperkuat oleh rata-rata prestes sebesar 62,40 dan data postes sebesar 77,80.Dengan demikian, terdapat perbedaan hasil tes kepewaraan antara sebelum dan sesudah pelatihan .

Berdasarkan hasil tes dan pelatihan kepewaraan model OEKIER tersebut di atas, ternyata perlu adanya unsur penunjang yang harus dilatihkan dan diteskan kepada peserta yang meliputi etika, estetika, kecakapan akademik, kecakapan sosial, dan kecakapan vokasional. Unsur utama kebahasaan dan nonkebahasaan yang selama ini dipakai dari berbagai rujukan dalam tes berbicara seperti pada tabel berikut, kiranya perlu ditambah dengan unsur penunjang. 
Tabel 8. Perbandingan Pengetahuan kebahasaan dalam Keterampilan Berbicara (kepewaraan)

\begin{tabular}{|c|c|c|c|}
\hline $\begin{array}{lll}\text { Maidar } & \text { G. } & \text { Arsjad } \\
\text { (1988) } & & \end{array}$ & $\begin{array}{l}\text { Duwi rahayu dkk } \\
\text { (Jurnal Basataka } \\
\text { Univ.Balikpapan) }\end{array}$ & $\begin{array}{l}\text { Sabarti } \\
\text { (1991) }\end{array}$ & $\begin{array}{ll}\text { Rokhman } & \text { dan } \\
\text { Pristiwati (2015 } & \end{array}$ \\
\hline 1.Ketepatan ucapan & 1.ketepatan ucapan & 1.pelafalan bunyi & 1.pelafalan \\
\hline 2.penempatan & 2.penempatan & 2.penempatan & 2.diksi \\
\hline $\begin{array}{l}\text { tekanan, nada, sendi, } \\
\text { durasi }\end{array}$ & $\begin{array}{l}\text { tekanan, nada, sendi, } \\
\text { dan durasi }\end{array}$ & $\begin{array}{l}\text { tekanan, } \text { nada, } \\
\text { jangka, intonasi, }\end{array}$ & $\begin{array}{l}\text { 3.variasi intonasi } \\
\text { 4.keefektifan kalimat }\end{array}$ \\
\hline $\begin{array}{l}\text { 3.diksi } \\
\text { 4.ketepatan sasaran } \\
\text { pembicaraan }\end{array}$ & $\begin{array}{l}\text { 3.diksi } \\
\text { 4.ketepatan } \\
\text { pembaca }\end{array}$ & $\begin{array}{l}\text { ritme } \\
\text { 3.penggunaan kata } \\
\text { dan kalimat }\end{array}$ & $\begin{array}{l}\text { 5.kaidah penyusunan } \\
\text { kalimat }\end{array}$ \\
\hline
\end{tabular}

Tabel 9. Perbandingan Pengetahuan Nonkebahasaan dalam Keterampilan Berbicara (kepewaraan)

\begin{tabular}{|c|c|c|c|}
\hline $\begin{array}{lll}\text { Maidar } & \text { G. } & \text { Arsjad } \\
(1988) & & \end{array}$ & $\begin{array}{l}\text { Duwi Rahayu dkk } \\
\text { (Jurnal Basataka } \\
\text { Univ.Balikpapan) }\end{array}$ & $\begin{array}{l}\text { Sabarti } \\
(1991)\end{array}$ & $\begin{array}{l}\text { Rokhman dan } \\
\text { Pristiwati (2015) }\end{array}$ \\
\hline $\begin{array}{l}\text { 1.Sikap wajar, tenang, } \\
\text { tidak kaku }\end{array}$ & $\begin{array}{l}\text { 1.Sikap wajar, tenang, } \\
\text { dan tidak kaku }\end{array}$ & $\begin{array}{l}\text { 1.Kenyaringan suara } \\
\text { 2.Kelancaran }\end{array}$ & $\begin{array}{l}\text { 1.Ketenangan } \\
\text { sikap }\end{array}$ \\
\hline 2.Pandangan & 2.Pandangan ke arah & 3.Penguasaan topik & 2.Tampil \\
\hline 3.Kesediaan & lawan bicara & 4.Sikap berbicara & mempesona \\
\hline menghargai orang lain & 3.Kesediaan & 5.Gerak-gerik & 3.Cerdas \\
\hline 4.Mimik & menghargai pendapat & mimik 1 & penuh prakarsa \\
\hline 5.Kenyaringan suara & orang lain & 6.Pen & 4.pro \\
\hline 6.Kelancaran & 4.Gerak-gerik & 7.Santun berbicara & 5.Mandiri \\
\hline 7.Relevansi/ penalaran & mimik & & 6.Sabar \\
\hline \multirow[t]{4}{*}{ 8.Penguasaan topik } & 5.Kenyaringan suara & & yang \\
\hline & $6 . \mathrm{K}$ & & \\
\hline & & & \\
\hline & 8.Penguasaan topik & & \\
\hline
\end{tabular}

Dari kedua tabel tersebut di atas, kiranya perlu dikembangkan unsur lain dalam kepewaraan yaitu unsur penunjang.
Dengan demikian akan tampak pada arsiran gambar berikut.

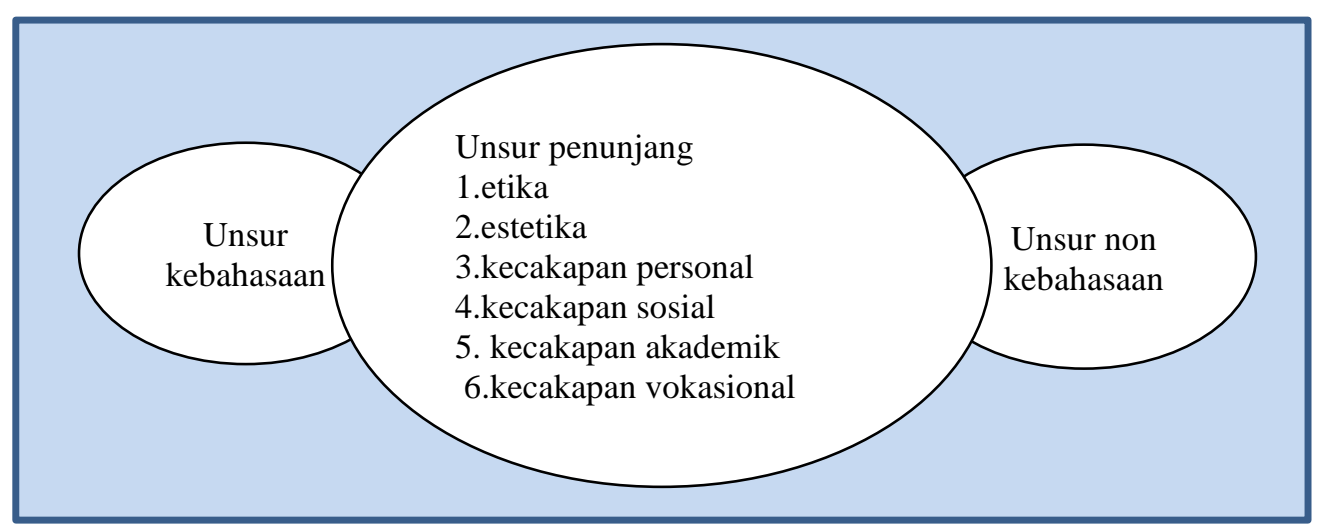

Gambar 2. Arsiran unsur kepewaraan 


\section{SIMPULAN}

Berdasarkan pembahasan di atas, perlu penulis simpulkan bahwa model evaluasi bebas tujuan pada pelatihan kepewaraan muncul temuan baru (novelty) saat program pelatihan berjalan dan hal itu tidak direncanakan sebelumnya. Temuan yang didapat berupa unsur penunjang, yaitu etika, estetika, kecakapan personal, kecakapan sosial, kecakapan akademik, dan kecakapan vokasional. Dengan demikian, benar apa kata Scriven (1974) bahwa evaluasi bebas tujuan adalah memalingkan dari tujuan evaluasi. Menurut Scriven, dalam melaksanakan evaluasi program, evaluator tidak perlu memperhatikan apa yang menjadi tujuan program. Oleh karena itu, sebaiknya model pelatihan kepewaraan ini perlu terus dikembangkan dengan aspek lain oleh beberapa perguruan tinggi di Indonesia. Model evaluasi bebas tujuan sebaiknya dipadukan dengan model evaluasi tujuan.

\section{DAFTAR RUJUKAN}

Akhadiyah, S., dkk. (1992). Bahasa Indonesia 1. Jakarta: Departemen Pendidikan dan Kebudayaan.

Arsjad, M. G. (1988). Pembinaan Kemampuan Berbicara Bahasa Indonesia. Jakarta: Erlangga.

Asrul, dkk. (2014). Evaluasi Pembelajaran. Medan: Ciptapustaka Media.

Hasan, S. H. (2009). Evaluasi Kurikulum. Bandung: Remaja Rosda Karya.

Joyce, B., Weil, M., \& Calhoun, E. (2009). Models of Teaching. New Jersey: Pearson Education Inc.

Kaufma, R. \& Thomson, S. (1980). Evaluation Without Fear. New York: Newviewpoints Division, Franklin Watts, Inc.

KBBI. (2001). Jakarta, Indonesia: Balai Pustaka.
Morreale and Pearson. (2008). Why Communication Education is Important: The Centrality of The Discipline in The 21st Century. Communication Education, 57 (2) (2008),

pp.224-240, http://dx.doi.org/10.1080/036345207 $\underline{01861713}$

Mutrofin. (2010). Evaluasi Program. Yogyakarta: Laksbang Presindo.

Nurgiantoro, B. (2001). Penilaian dalam Pengajaran Bahasa dan Sastra. Yogyakarta, Indonesia: BPFE

Rahayu, D., dkk. (2018). Kemampuan Berbicara Siswa MTs Hidayatul Mustaqim Balikpapan Melalui Kegiatan Menjadi Pembawa Acara. Jurnal Bastaka no 1 Juni 2018.

Rokhman, F. \& Pristiwati, R. (2015). Kepewaraan di Perguruan Tinggi. Yogyakarta, Indonesia: CV Andi Offset.

Scriven, M. (1974). Standard for the Evaluation of Educational Programs and Products. In. G. D. Borich (Ed). Evaluating Educational Programs and Products. Engliwood Cliffs. N.J. Educational Technology Publication.

Stufflebeam, D. L. (1971). Evaluation as Enlighment for Decision Making. Ohio: Ohio State University.

Zulaeha, Ida. (2013). Pengembangan Model Pembelajaran Keterampilan Berbahasa Indonesia Berkonteks Multikultural. Jurnal Litera, 12(1), 97-105.

Doi https://doi.org/10.21831/ltr.v12i01.13 $\underline{31 .}$ 
84 JURNAL PENDIDIKAN EDUTAMA, Vol.8, No.2 Juli 2021 